\title{
Holocord Astrocytoma
}

-Case Report-

\author{
Tetsuro IRIKURA, Tatsuhiro JOHKI, Hideaki TANAKA, \\ Masato NAKAJIMA, Masaharu YASUE, Haruo SAKaI \\ and Norio NAKAMURA
}

Department of Neurosurgery, The Jikei University School of Medicine, Tokyo

\begin{abstract}
A rare case of intramedullary holocord astrocytoma extending from the medulla oblongata to the conus medullaris is reported. A 27 -year-old male who had been suffering from nuchalgia for a few years was admitted to our department because of lumbago and gait disturbance. Neurological examination revealed sensory disturbances in various locations, weakness of the right lower extremity, mild swallowing disturbance, and bowel and bladder difficulties. Magnetic resonance (MR) images and myelograms showed a long cystic lesion extending from the medulla oblongata to the thoracolumbar spinal cord. Gadolinium-diethylenetriaminepenta-acetic acid (Gd-DTPA)-enhanced images detected a solid tumor located at the Th6-7 level. Two syrinx-subarachnoid shunts were placed at the upper cervical and Th12 levels. The solid neoplasm at the Th7 level was partially resected and histologically diagnosed as astrocytoma. Differentiation between cystic lesions and solid masses in the spinal cord is difficult. The usefulness of Gd-DTPA-enhanced MR imaging in the diagnosis of holocord tumor and the pathogenesis of secondary syringomyelia are discussed.
\end{abstract}

Key words: holocord tumor, pan-spinal tumor, pan-medullary tumor, astrocytoma, intramedullary tumor

\section{Introduction}

Spinal intramedullary tumors affecting the entire cord are rare; few such cases have been reported since the first by Cushing in $1927{ }^{6)}$ Despite the advances in magnetic resonance (MR) imaging facilitating diagnosis, differentiation between solid masses and cystic lesions is still difficult. Moreover, there are still some problems in the treatment of this disorder. We report here a case of holocord astrocytoma topologically diagnosed by using gadoliniumdiethylenetriaminepenta-acetic acid (Gd-DTPA)-enhanced MR imaging.

\section{Case Report}

A 27-year-old male was admitted to the neurosurgical department of The Jikei University Hospital on April 21, 1988, because of progressive lumbago, sphincter dysfunction, unsteady gait, and dyspha-

\footnotetext{
Received June 19, 1989; Accepted October 6, 1989
}

gia. He had suffered from nuchalgia for 5 years and loss of pain and temperature sensations on the left upper extremity for 9 months.

Sensory examination on admission demonstrated analgesia on the left side including the face and marked hypesthesia on the left upper and bilateral lower extremities and the pubes. He could not walk unaided due to weakness of the right lower extremity. The deep tendon reflexes were exaggerated in the bilateral lower extremities. Swallowing disorders and bladder and bowel dysfunctions were observed.

Plain spinal $x$-ray films were normal. Lumbar myelograms showed a defect in the contrast medium shaped like a rugby ball, $17 \mathrm{~mm}$ in diameter, and 50 $\mathrm{mm}$ in length at the Th12 level and partial block by the swollen cord above this level (Fig. 1). Suboccipital myelograms showed a tapering block at the upper thoracic level. $T_{1}$-weighted MR images demonstrated a low-intensity lesion extending from the medulla to the thoracic cord (Fig. 2), which was high intensity on the $\mathrm{T}_{2}$-weighted images. Coronal MR images with a surface coil showed a solitary 


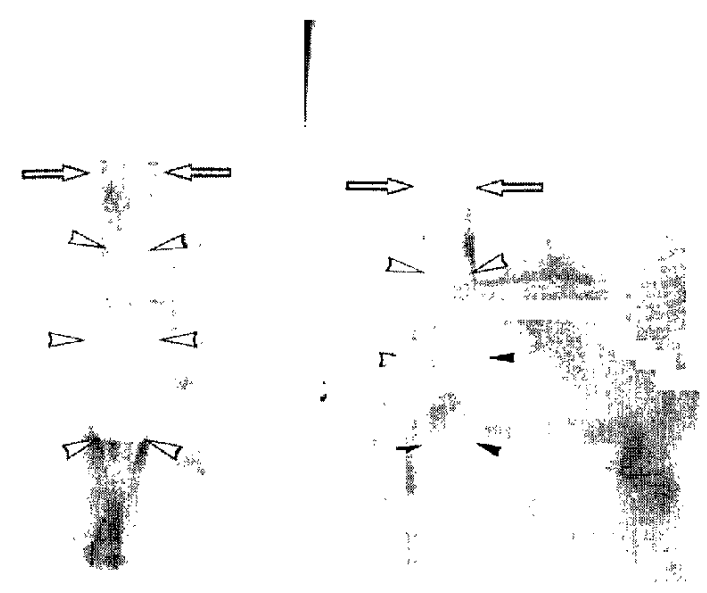

Fig. 1 Lumbar myelograms, showing a rugby-balllike defect at the Th12 level (arrowheads) and partial block above this level (arrows).

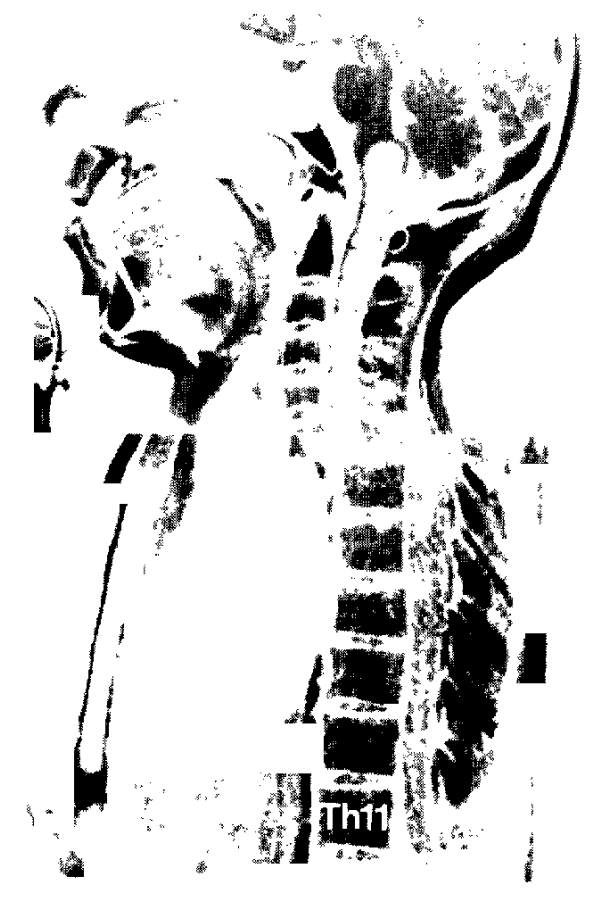

Fig. $2 T_{1}$-weighted MR images, showing a cystic lesion extending from the medulla oblongata to the thoracic spinal cord.

high-intensity lesion at the Th12 level. Under the diagnosis of an ependymoma of the conus medullaris accompanied by syringomyelia developing superiorly, an operation was performed.

A laminectomy from Th11 to Ll followed by a small incision in the swollen cord revealed a syrinx containing xanthochromic fluid. The syrinx continu- ously extended rostrally but ended in a blind sac caudally. Biopsy of the cystic wall demonstrated proliferation of reactive astrocytes but no tumorous components. A shunt tube was placed between the syrinx and the subarachnoid space (Fig. 3). An occipital craniotomy and laminectomy at $\mathrm{Cl}$ were then performed to expose the swollen medulla oblongata and upper cervical cord. A small incision 2-3 $\mathrm{mm}$ in depth into the fasciculus gracilis revealed the large syrinx. A shunt tube was placed between the syrinx and the cervical subarachnoid space. There was no communication between the fourth ventricle and the syrinx, and no tumor was discovered.

Postoperatively, both syringomyelia and syringobulbia contracted. Postoperative Gd-DTPA-enhanced MR images revealed high-intensity, swollen spinal cord centered at the Th6 and 7 levels (Fig. 4). Since this was suspected to be a solid tumor, a second operation was performed.

After laminectomy from Th5 to 8, the yellowish, swollen spinal cord with abnormal vessels was ob-

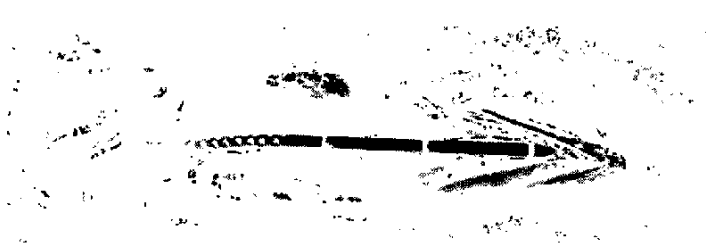

Fig. 3 Operative photograph, showing the spinal cord exposed at the Th12 level. The syringomyelic cavity was opened, and a syrinx-subarachnoid shunt emplaced.

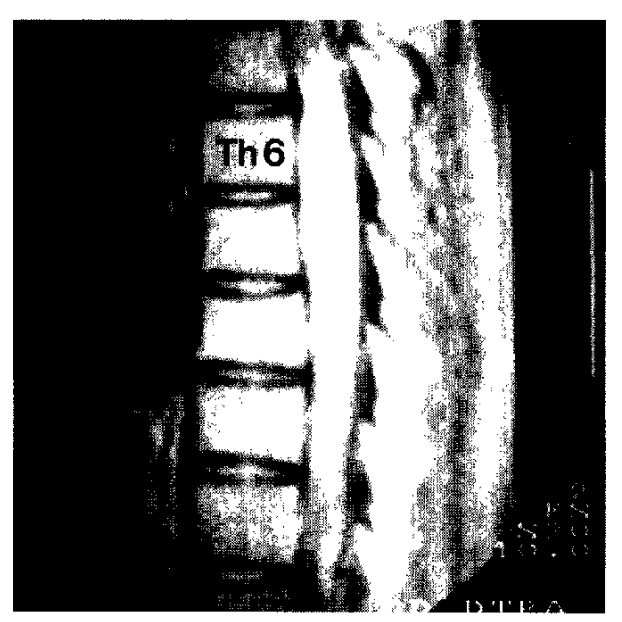

Fig. 4 Postoperative Gd-DTPA-enhanced MR image, showing intense enhancement of swollen cord at Th6-7. 


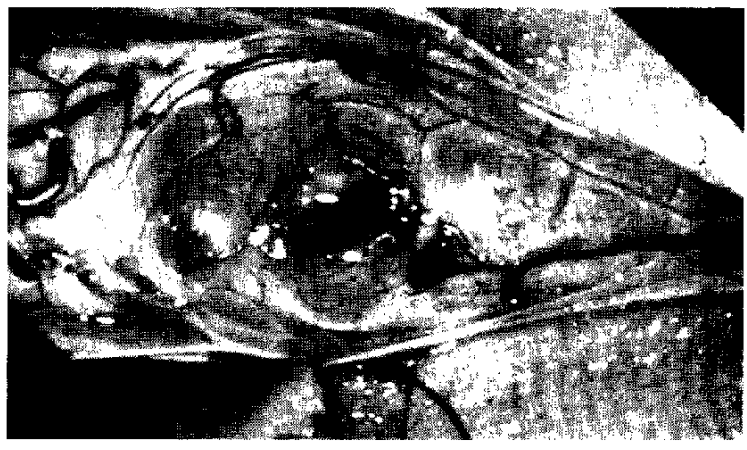

Fig. 5 Operative photograph, showing a solid tumor in the spinal cord at Th6-7.

served. It was partially excised at Th7 (Fig. 5) and histologically diagnosed as astrocytoma.

Postoperative focal irradiation of 47.7 Gy was performed. The swallowing difficulties, nuchalgia, and back pain disappeared. The sensation and thermal paresthesia on the left upper extremity and trunk and weakness of the right lower extremity were improved. Nine months later, he returned to his employment.

\section{Discussion}

Spinal intramedullary tumors sometimes extend both superiorly and inferiorly along almost the entire cord. This has been known for a long time since the first report by Cushing ${ }^{6}$ in 1927 followed by Horrax and Henderson ${ }^{15)}$ in 1939. Fischer et al. ${ }^{12)}$ reported two cases of ependymoma using the term "panspinal" ependymoma. Epstein and Epstein" reported three cases of astrocytoma and called them "holocord" tumors. All these cases had a cyst extending over several vertebrae. An unusual, panspinal intramedullary tumor, which was a solid mass not accompanied by a cyst, was termed as a "pan-medullary" tumor by Tedeschi et al. ${ }^{32)}$ Thus, spinal intramedullary tumors growing along the entire cord are usually accompanied by a cyst and, regardless of the proportion of the solid mass to the cyst, are classified as mentioned above. According to Nikaido et $a l .{ }^{26)}$ and Tanaka et al., ${ }^{31)}$ we have decided to use the term holocord tumor.

The incidence of holocord tumor in children has been reported to be $3-8 \%$ of all spinal tumors ${ }^{5,29)}$ and $8 \%$ of all intramedullary tumors ${ }^{33)}$ and, including adults, $5 \%$ of all intramedullary tumors. ${ }^{14)} \mathrm{A}$ summary of detailed reports on holocord tumors containing 24 cases, including ours, is given in Table 1. Such tumors usually oceur in young patients (mean age, 14.1 years) and in males (male to female ratio, 15:9). The initial symptoms include motor paresis and pain as in other spinal tumors. Examination may reveal irregular sensory impairment at any level of the spinal cord.

The tumor histology was ependymoma in eight cases, astrocytoma in seven, teratoma in five, lymphoma in one, small cell glioma in one, and ganglioglioma in one. In the teratomas, a large part of the tumor was located intramedullary. Interestingly, almost all the holocord tumors were accompanied by cysts regardless of the histological tumor type, and such cysts could be classified into two types. Type I consists of multiple small cysts within the tumor and is most frequently observed in teratomas and astrocytomas. Type II consists of a large cyst formed above and/or below the tumor mass, and the wall of this type cyst sometimes has Rosenthal fibers but no tumor cells. Liber and Lisa ${ }^{20)}$ observed Rosenthal fibers also in non-neoplastic syringomyelia. Thus, these fibers are not a characteristic feature of the wall of the cyst accompanying tumors and, moreover, do not indicate the presence of tumor. At present, it is unclear whether the term syrinx or cyst should be used for liquid retention associated with tumor, but in general, the term cyst is preferred. Only large cysts with the wall containing no tumor cells, as type II, are termed secondary syringomyelia.

Although reports of holocord tumors are rare, secondary development of syringomyelia in cases of spinal intramedullary tumor is not rare, with the reported incidence of $16-58 \% .{ }^{11,18,21)}$ Tannenberg suggested that this is due to retention of tissue fluid caused by pressure from the tumor. ${ }^{21)}$ JonescoSisesti ${ }^{16)}$ reported different congenital causes for syringomyelia and the tumor. Russell ${ }^{28}$ stated that the syrinx results from a secondary effect of ischemia or tumoral hemorrhage. Liber and Lisa ${ }^{20)}$ believed that the blockade of the perivascular space by the tumor cells hampers drainage of tissue fluid and forms the syrinx. Feigin et al. ${ }^{10)}$ advocated an important role of edema in the formation of the syrinx. However, it is difficult to believe that such a long syrinx could be formed only by the above mechanisms, so there must be some other mechanisms developing the syrinx. In regard to the primary cause of syringomyelia, Ball and Dayan ${ }^{21}$ suggested that as the pressure in the spinal canal increases, the cerebrospinal fluid (CSF) extends into the medulla via the perivascular space, and Williams ${ }^{35}$ also emphasized pressure changes in the spinal canal. Nagahiro et $a l^{23,24)}$ reported that such abnormal CSF circulation is likely to occur under conditions in which a tethering or subarachnoid block is caused by the tumor. A reported case 
Table 1 Intramedullary holocord tumors

\begin{tabular}{|c|c|c|c|c|c|c|c|}
\hline Author (Year) & Age & Sex & $\begin{array}{l}\text { Location } \\
\text { of tumor }\end{array}$ & $\begin{array}{l}\text { Location } \\
\text { of cyst }\end{array}$ & Tumor histology & Surgery & Result \\
\hline Cushing $(1927)^{6)}$ & 8 yrs & $\mathrm{F}$ & medulla-conus & Th2-conus & ependymoma & total removal & improved \\
\hline $\begin{array}{l}\text { Horrax and Henderson } \\
(1939)^{15)}\end{array}$ & 20 yrs & $\mathbf{F}$ & medulla-conus & Th9-conus & ependymoma & total removal & improved \\
\hline \multirow[t]{2}{*}{ Lowenberg $(1939)^{*}$} & $14 \mathrm{yrs}$ & $\mathbf{M}$ & medulla-lumbar & multiple & astrocytoma & $?$ & $?$ \\
\hline & 26 yrs & $\mathrm{F}$ & medulla-conus & multiple & $?$ & $?$ & $?$ \\
\hline $\begin{array}{l}\text { Black and German } \\
(1950)^{3)}\end{array}$ & $5 \operatorname{mos}$ & $\mathbf{M}$ & medulla-conus & conus & teratoma & partial removal & $\begin{array}{l}\text { died after } \\
10 \mathrm{yrs}\end{array}$ \\
\hline $\begin{array}{l}\text { David et al. } \\
\quad(1965)^{7}\end{array}$ & 32 yrs & $\mathrm{M}$ & $\mathrm{C} 1-\mathrm{L} 1$ & $?$ & $\begin{array}{l}\text { small cell } \\
\text { glioma }\end{array}$ & total removal & no change \\
\hline $\begin{array}{l}\text { Mikagi et al. } \\
(1968)^{22)}\end{array}$ & $6 \operatorname{mos}$ & $\mathbf{M}$ & pons-conus & multiple & teratoma & - & died \\
\hline \multirow[t]{2}{*}{$\begin{array}{l}\text { Fischer et al. } \\
\quad(1975)^{121}\end{array}$} & 27 yrs & $\mathrm{F}$ & medulla-conus & $\begin{array}{l}\text { upper part, } \\
\text { lower part }\end{array}$ & ependymoma & $?$ & $?$ \\
\hline & 24 yrs & $\mathrm{M}$ & $\mathrm{C} 2-\mathrm{L} 2$ & $\begin{array}{l}\text { cervical, } \\
\text { dorsal-lumbar }\end{array}$ & ependymoma & total removal & improved \\
\hline $\begin{array}{l}\text { Pickens et al. } \\
(1975)^{27)}\end{array}$ & $6 \mathrm{wks}$ & $\mathrm{F}$ & medulla-conus & multiple & teratoma & - & died \\
\hline $\begin{array}{l}\text { Kajita et al. } \\
\quad(1975)^{173}\end{array}$ & $4 \operatorname{mos}$ & $\mathrm{F}$ & $\begin{array}{l}\text { upper cervical- } \\
\text { conus }\end{array}$ & multiple & teratoma & - & died \\
\hline $\begin{array}{l}\text { de Divitiis et al. } \\
(1978)^{8)}\end{array}$ & 31 yrs & $\mathbf{M}$ & $\mathrm{C} 1-\mathrm{L} 1$ & Th6?-L1 & ependymoma & total removal & improved \\
\hline $\begin{array}{l}\text { Albright and Byld } \\
(1980)^{1)}\end{array}$ & $11 \mathrm{yrs}$ & $\mathrm{M}$ & medulla-conus & $\begin{array}{l}\text { medulla-C5, } \\
\text { conus }\end{array}$ & ganglioglioma & total removal & improved \\
\hline$\underset{(1980)^{25)}}{\text { Nakamura et al. }}$ & $6 \mathrm{yrs}$ & $\mathrm{F}$ & pons-conus & - & ependymoma & - & died \\
\hline \multirow[t]{3}{*}{$\begin{array}{l}\text { Epstein and Epstein } \\
(1981)^{9)}\end{array}$} & $15 \mathrm{yrs}$ & $\mathbf{M}$ & medulla-conus & $\begin{array}{l}\text { medulla-C4, } \\
\text { lower part }\end{array}$ & astrocytoma & subtotal removal & improved \\
\hline & $5 \mathrm{yrs}$ & $\mathbf{M}$ & medulla-conus & $\begin{array}{l}\text { medulla-C4, } \\
\text { Th9-conus }\end{array}$ & astrocytoma & subtotal removal & improved \\
\hline & $4 \mathrm{yrs}$ & $\mathrm{M}$ & medulla-conus & $\begin{array}{l}\text { medulla-c4, } \\
\text { Th4-conus }\end{array}$ & astrocytoma & subtotal removal & improved \\
\hline $\begin{array}{l}\text { Tedeschi et al. } \\
\quad(1982)^{32)}\end{array}$ & $12 \mathrm{yrs}$ & $\mathrm{F}$ & $\mathrm{C} 1-\mathrm{L} 2$ & multiple & astrocytoma & subtotal removal & improved \\
\hline $\begin{array}{l}\text { Nikaido et al. } \\
\quad(1984)^{26)}\end{array}$ & $2 \mathrm{yrs}$ & $\mathbf{M}$ & C4-conus & $\begin{array}{l}\text { C4-Th3, } \\
\text { Th8-conus }\end{array}$ & astrocytoma & subtotal removal & died \\
\hline $\begin{array}{l}\text { Nagahiro et al. } \\
(1986)^{24)}\end{array}$ & $23 \mathrm{yrs}$ & $\mathrm{M}$ & medulla-filum & medulla-Th 12 & ependymoma & total removal & improved \\
\hline$\underset{(1986)^{31)}}{\text { Tanaka et }}$ & $14 \mathrm{yrs}$ & $\mathbf{M}$ & medulla-filum & medulla-conus & ependymoma & total removal & improved \\
\hline $\begin{array}{l}\text { Landan et al. } \\
\quad(1987)^{19)}\end{array}$ & 37 yrs & $\mathrm{F}$ & C2-conus & C2-conus & $\begin{array}{l}\text { primary } \\
\text { lymphoma }\end{array}$ & myelotomy & died \\
\hline $\begin{array}{l}\text { Urui and Oi } \\
\qquad(1988)^{34)}\end{array}$ & 67 days & $\mathrm{M}$ & whole cord & $?$ & teratoma & partial removal & no change \\
\hline Present case & $27 \mathrm{yrs}$ & $\mathrm{M}$ & medulla-conus & $\begin{array}{l}\text { medulla-Th5, } \\
\text { Th9-conus }\end{array}$ & astrocytoma & partial removal & improved \\
\hline
\end{tabular}

${ }^{*}$ Cited from Tanaka et al. ${ }^{31)}$

of syringomyelia associated with extramedullary meningioma ${ }^{4}$ suggests that the same mechanism involved with primary syringomyelia develops the syrinx associated with the tumor. ${ }^{13}$ )

Radiological examination for holocord tumor includes plain spinal $x$-rays, which reveal the widening of the space between the pedicles of the vertebral arches and depressions in the vertebral bodies, and myelography, which shows enlargement of the spinal cord. Imaging diagnosis has been greatly facilitated by the development of MR imaging. Tanaka et al. ${ }^{31)}$ investigated the MR findings for an ependymoma accompanied by a holocord cyst and differentiated the tumor from the syringomyelia by comparing the $T_{1}$ values. Slasky et $a l .{ }^{30)}$ found that, in the differential diagnosis between the spinal cord tumor and the syrinx or cyst, MR imaging following the administration of Gd-DTPA was useful. In our case, MR imag- 
ing could easily identify the cystic lesion extending from the medulla oblongata to the cervical spine. However, a topological diagnosis of the solid mass was difficult. Since myelography demonstrated swollen spinal cord, the coronal images of the thoracic and lumbar spine using a surface coil were obtained but were unable to delineate the tumor mass. Only after administration of Gd-DTPA, was the actual tumor mass adequately identified.

Most ependymomas can be completely extirpated since the edge of the tumor is clearly defined. However, astrocytomas do not have clearly defined borders so that surgical treatment is still debatable. Epstein and Epstein ${ }^{9)}$ reported that although an extensive posterior myelotomy alone did not cause neurological deficit, excessive manipulation during the operation may cause permanent damage. They achieved success in conducting complete macroscopic extirpation using an ultrasonic surgical aspirator. Tedeschi et al ${ }^{32)}$ also reported successful complete macroscopic extirpation of solid astrocytoma. However, Guidetti et al. ${ }^{14)}$ reported that since the borders of most astrocytomas are unclear, complete extirpation is difficult and may frequently cause aggravation of neurological symptoms. In our case, since the border of the actual tumor was unclear, only laminectomy and partial extirpation were performed. Also, since no tumor cells were observed in the wall of the syrinx, complete extirpation of the syrinx was very likely to result in aggravation of the neurological symptoms, so a shunt tube was placed between the syrinx and the subarachnoid space.

\section{References}

1) Albright L, Byld RP: Ganglioglioma of the entire spinal cord. Childs Brain 6: 274-280, 1980

2) Ball MJ, Dayan AD: Pathogenesis of syringomyelia. Lancet 2: 799-801, 1972

3) Black SPW, German WJ: Four congenital tumors found at operation within the vertebral canal: With observations on their incidence. $J$ Neurosurg 7: 4961,1950

4) Blaylock RL: Hydrosyringomyelia of the conus medullaris associated with a thoracic meningioma. $J$ Neurosurg 54: 833-835, 1981

5) Coxe WS: Tumors of the spinal canal in children. Amer Surg 27: 62-73, 1961

6) Cushing $\mathrm{H}$ : The intracranial tumors of preadolescence. Amer J Dis Child 33: 551-584, 1927

7) David M, Hirsch JF, Sachs M, Guyot JF: Réflexions sur trois cas de tumeurs intramédullaires opérées. Neurochirurgie 11: 557-570, 1965

8) de Divitiis E, Spaziante R, Stella L: Giant intramedullary ependymoma. A case report. Neurochirurgia (Stuttg) 21: 69-72, 1978
9) Epstein F, Epstein N: Surgical management of holocord intramedullary spinal cord astrocytomas in children. Report of three cases. I Neurosurg 54: 829832,1981

10) Feigin I, Ogata J, Budzilovich G: Syringomyelia: The role of edema in its pathogenesis. $I$ Neuropathol Exp Neurol 30: 216-232, 1971

11) Ferry DJ, Hardman JM, Earle KM: Syringomyelia and intramedullary neoplasms. Med Ann DC 38: 363-365, 1969

12) Fischer G, Pierluca P, Sindou M, Pialat J: L'épendymome pan-médullaire. A propos de deux cas déxérèse complète. Neurochirurgie 21: 5-20, 1975

13) Gardner WJ, McMurry FG: "Non-communicating'" syringomyelia: A non-existent entity. Surg Neurol 6: 251-256, 1976

14) Guidetti B, Mercuri S, Vagnozzi R: Long-term results of the surgical treatment of 129 intramedullary spinal gliomas. J Neurosurg 54: 323-330, 1981

15) Horrax G, Henderson DG: Encapsulated intramedullary tumor involving the whole spinal cord from medulla to conus: Complete enucleation with recovery. Surg Gynec Obstet 68: 814-819, 1939

16) Jonesco-Sisesti N: Tumeurs Médullaires Associées à un Processus Syringomyélique. Paris, Masson \& Cie, 1929

17) Kajita A, Otsuka S, Fukuyama S, Tsuchiya A, Sugiura S: An autopsy case of spinal cord teratoma. Nippon Rinsho 33: 2417-2419, 1975 (in Japanese)

18) Kernohan JW, Woltman HW, Adson AW: Intramedullary tumors of the spinal cord: A review of 51 cases, with an attempt at histologic classification. Arch Neurol Psychiat 25: 679, 1931

19) Landan I, Gilroy J, Wolfe DE: Syringomyelia affecting the entire spinal cord secondary to primary spinal intramedullary central nervous system lymphoma. J Neurol Neurosurg Psychiatry 50: 15331535,1987

20) Liber AF, Lisa JR: Rosenthal fibers in nonneoplastic syringomyelia. A note on the pathogenesis of syringomyelia. J Nerv Ment Dis 86: 549-559, 1937

21) Mackay RP, Favill J: Syringomyelia and intramedullary tumor of the spinal cord. Arch Neurol Psychiat 33: 1255-1278, 1935

22) Mikagi $Y$, Mitsuyasu $Y$, Inoue K, Fujii H: An autopsy case of intramedullary teratoma with longitudinal extension to the whole spinal cord. Fukuoka Igaku Zasshi 59: 828-840, 1968 (in Japanese)

23) Nagahiro S, Matsukado $Y$, Hirata $Y$, Saito $Y$, Hamada J, Fukumura A, Itoyama Y: Pathogenesis and treatment of the secondary syringomyelia. No To Shinkei 39: 143-149, 1987 (in Japanese)

24) Nagahiro S, Matsukado Y, Kuratsu J, Saito $Y$, Takamura S: Syringomyelia and syringobulbia associated with an ependymoma of the cauda equina involving the conus medullaris: Case report. Neurosurgery 18: 357-360, 1986

25) Nakamura S, Yamada $H$, Tajima M, Yoshida J, Kobayashi T, Kageyama N: Intramedullary tumor in-

Neurol Med Chir (Tokyo) 30, November, 1990 
volving from brain stem to conus medullaris. Shoni No Noshinkei 5: 199-203, 1980 (in Japanese)

26) Nikaido $Y$, Ohnishi $H$, Hiramatsu $K$ : Intramedullary holocord tumor: Report of an autopsy case and review of literature. No Shinkei Geka 12: 523-528, 1984 (in Japanese)

27) Pickens JM, Wilson J, Myers GG, Grunett ML: Teratoma of the spinal cord. Report of a case and review of the literature. Arch Pathol Lab Med 99: 446-448, 1975

28) Russell DS: Capillary hemangioma of spinal cord associated with syringomyelia. J Pathol 135: 103-112, 1978

29) Seki H, Mori T, Tanaka A: Spinal cord tumors within first year of life: Report of a case and analysis of the literatures. Shoni No Noshinkei 3: 197-204, 1978 (in Japanese)

30) Slasky BS, Bydder GM, Niendolf HP, Young IR: MR imaging with gadolinium-DTPA in the differentiation of tumor, syrinx, and cyst of the spinal cord. $J$ Comput Assist Tomogr 11: 845-850, 1987

31) Tanaka H, Shimizu H, Ishijima B, Nakamura $Y$ : Myxopapillary ependymoma of the filum terminale with a holocord cyst: A case report. No Shinkei Geka 14: 997-1003, 1986 (in Japanese)

32) Tedeschi G, Spaziante R, Corriero G, Gambardella A, Pettinato G: A case of pan-medullary astrocytoma in a child. Neurochirurgia (Stuttg) 25: 27-30, 1982

33) Tsubokawa T, Miyagami M, Murakami T, Moriyasu N: Spinal cord tumors of neonatus. Shoni Geka Naika 7: 1181-1188, 1975 (in Japanese)

34) Urui $S$, Oi S: Congenital intramedullary teratoma involving the entire spinal cord and brain stem associated with hydrocephalus. CT Kenkyu 10: 223-228, 1988 (in Japanese)

35) Williams B: On the pathogenesis of syringomyelia: A review. J $R$ Soc Med 73: 798, 1980

Address reprint requests to: T. Irikura, M.D., Department of Neurosurgery, The Jikei University School of Medicine, 3-25-8 Nishishinbashi, Minato-ku, Tokyo 105, Japan. 